\title{
ANALYSIS OF THE IMPACT OF INTANGIBLE RESOURCES AT MACROECONOMIC LEVEL. THE CASE OF ROMANIA
}

\author{
Sebastian Emanuel STAN \\ "Nicolae Bălcescu" Land Forces Academy, Sibiu, Romania \\ office.sstan@gmail.com
}

\begin{abstract}
The results of literature analysis confirm the strategic value of intangible resources in creating wealth and conferring competitive advantages to nations. However, there are few academic papers related to intangible resources at country level. At national level, economic growth is increasingly based on knowledge and other intangible resources than on physical ones. To test this hypothesis in Romania, this article analyses how intangible resources influence economic growth, and correlation indices between different types of intangible resources and gross domestic product value are calculated. The analysis shows that there are very strong positive correlations between GDP and most of the intangible resource variables. Despite the importance of intangible resources at national level and the fact that they are an important factor in determining economic growth in the current knowledge-based economy, Romania's position in the international context regarding intangible assets is very weak, with many weak points in research and innovation performance compared to other EU Member States. Therefore, there is a need in our country to re-evaluate the areas where all efforts need to be focused to stimulate innovation performance, to properly manage national intangible resources, a crucial process for improving the quality of life.
\end{abstract}

\section{Keywords: intangible resources, economic growth, correlation, GDP}

\section{Introduction}

From the point of view of the studies regarding the microeconomic and macroeconomic impact of intangible resources, the first analysis were conducted at the level of firms to explain their market value [1] [2], investors being eager to incorporate intangible resources in the evaluations of the firms they are interested in. Subsequently, since intangible factors can have a major economic impact (although difficult to demonstrate and measure), their role has attracted increased interest in research, so governments, researchers and international organizations have developed new ways of measuring and managing intangibles at macroeconomic level. This happens because for any government, a fundamental obligation is to provide adequate conditions for economic growth and for improving the quality of its citizen's life.

This article is structured as follows: in the second section there are presented the general considerations regarding intangible resources and their impact on economic growth at the national level, the third section presents the methodology and the data that is used while the fourth section presents the obtained results. The article ends with the presentation of the conclusions.

2. General considerations regarding intangible resources and their impact on economic growth at the national level

Economic growth is a major objective for all states. The neoclassical economic model 
has been an important theoretical framework for studying economic growth and public policies in the last century. Under this theory, capital and labour can explain national growth and are characterized by their exogenous nature [3]. Robert Solow's 1950 studies included technological change between variables that explain growth. Solow [3] has shown that capital is not the only factor that determines the productivity. There are other important variables, such as research and education. The econometric model presented by Solow in 1956 described technological progress as the most important factor for a country's economic growth [4].

In the current social and economic context, knowledge and information become the core competencies of nations pursuing development, overcoming the importance of capital [5] or labour [6]. According to Foray [7], knowledge is a good asset for the new economy. This new conceptual framework, the knowledge-based economy, is the result of knowledge creation and exchange, where information and the communications sector are key elements, and intangible capital is more important than the tangible one [8].

The substantial impact of macroeconomic dynamics on firms and industries and the inability of traditional crisis prevention monitoring tools have highlighted the growing need for monitoring and analysing trends in the value of national intangible resources. As stated above, economic activity in many countries has shifted from the production of goods to the production of services, and at national level, economic growth is increasingly based on knowledge and other intangible resources than on physical resources [9].

\section{Methodology and data}

To test this hypothesis in the case of Romania, we analysed the way in which intangible resources influenced economic growth, and we calculated the correlation between different types of intangible resources and the value of gross domestic product.

In order to identify the types of intangible resources taken in the analysis, we used the intangible resources taxonomy that we proposed in a previous research [10] as the instrument through which we highlighted those elements that we considered representative for analysing and understanding intangible resources. In this classification, four relevant competitive intangible resources groups were identified: human capital, innovation, structural and relational capital, each group being composed of many intangible resources.

As a result, the variables pursued on the four dimensions of intangible resources are presented in Table 1 and Figures $1 \mathrm{a}$ and $1 \mathrm{~b}$. The values were extracted from the Global Competitiveness Reports for the period 2011-2017 (referring to 2010-2015 indicator values) issued by the World Economic Forum. Also, here are the values of the Pearson correlation coefficients recorded between the intangible resources variables and the annual gross domestic product value. In Table 1 all variables are expressed on a value scale of 1 , the minimum value, to 7 , the maximum, the optimal value. For the statistical processing of collected data, we used the EXCEL software.

\section{Results}

The analysis also shows that, in our country, there are very strong positive correlations between GDP and most of the intangible resources variables, the correlation coefficients ranging from 0.130.90 , confirming once again the obtained results by other specialized papers [11], [12], [13], [14] which have demonstrated a strong relationship between the intangible resources and economic development of a nation. 
Table 1 Correlation analysis between intangible resources variables and GDP in Romania

\begin{tabular}{|c|c|c|c|c|c|c|c|c|}
\hline \multicolumn{2}{|r|}{ Intangibile resurces } & 2015 & 2014 & 2013 & 2012 & 2011 & 2010 & Correl. \\
\hline \multirow{2}{*}{ 预 } & $\begin{array}{l}\text { Quality of the education } \\
\text { system }\end{array}$ & 2,8 & 3,3 & 3,8 & 3,3 & 3,1 & 3,3 & 0,40 \\
\hline & $\begin{array}{l}\text { The country's ability to } \\
\text { keep its talents }\end{array}$ & 2,1 & 2,3 & 2,5 & 2,1 & 2,1 & 2,2 & 0,55 \\
\hline \multirow{3}{*}{ 言 } & $\begin{array}{l}\text { The degree of customer } \\
\text { orientation }\end{array}$ & 4,6 & 4,8 & 4,4 & 4,1 & 4,0 & 4,1 & 0,13 \\
\hline & Quality of local suppliers & 4,3 & 4,2 & 4,1 & 4,0 & 3,9 & 4,0 & 0,90 \\
\hline & $\begin{array}{l}\text { Cooperation between } \\
\text { universities and industry in } \\
\text { R \& D }\end{array}$ & 3,3 & 3,6 & 3,6 & 3,3 & 3,1 & 3,0 & 0,51 \\
\hline \multirow{4}{*}{ 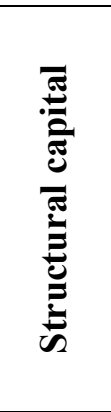 } & Ethical behavior of firms & 3,3 & 3,4 & 3,5 & 3,1 & 3,2 & 3,4 & 0,30 \\
\hline & $\begin{array}{l}\text { Level of technology } \\
\begin{array}{l}\text { absorption at company } \\
\text { level }\end{array}\end{array}$ & 4,3 & 4,4 & 4,4 & 4,3 & 4,1 & 4,1 & 0,33 \\
\hline & $\begin{array}{l}\text { Nature of competitive } \\
\text { advantage }\end{array}$ & 2,7 & 3,1 & 3,3 & 3,1 & 3,0 & 2,9 & 0,52 \\
\hline & $\begin{array}{ll}\begin{array}{l}\text { Sophistication } \\
\text { production processes }\end{array} & \text { of } \\
\end{array}$ & 3,4 & 3,7 & 3,7 & 3,4 & 3,2 & 3,3 & 0,36 \\
\hline \multirow{4}{*}{ 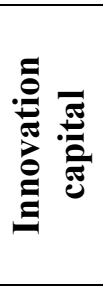 } & Innovation capacity & 4,0 & 4,0 & 3,7 & 3,4 & 3,1 & 2,9 & 0,30 \\
\hline & $\begin{array}{l}\text { The quality of scientific } \\
\text { research institutions }\end{array}$ & 3,8 & 3,7 & 4,0 & 3,7 & 3,4 & 3,2 & 0,58 \\
\hline & $\begin{array}{l}\text { Expenditure of } \mathrm{R} \& \mathrm{D} \\
\text { firms }\end{array}$ & 2,8 & 2,9 & 3,1 & 2,8 & 2,9 & 2,9 & 0,70 \\
\hline & Patent applications & 3,4 & 2,7 & 2,2 & 2,0 & 1,9 & 0,8 & 0,34 \\
\hline \multicolumn{2}{|c|}{ GDP (bill. US\$) } & 177,3 & 177.3 & 199.4 & 169,4 & 189,8 & 161,6 & 1,00 \\
\hline
\end{tabular}

Source: own processing using data provided by Global Competitiveness Reports, World Economic

Forum, 2010-2015 


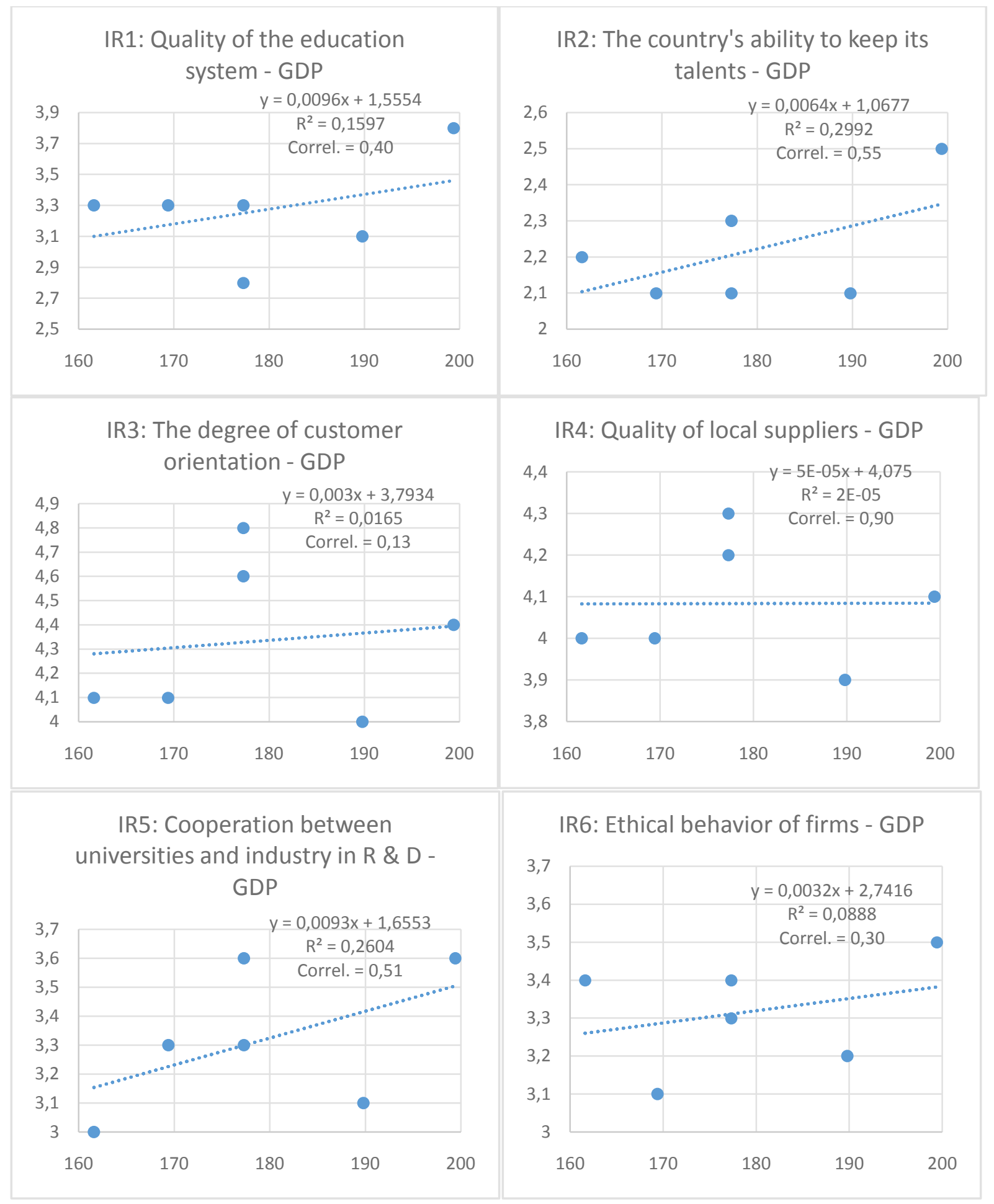

Figure 1.a: Correlation analysis between intangible resource variables (IRI-6) and GDP

Source: own processing using the EXCEL software 


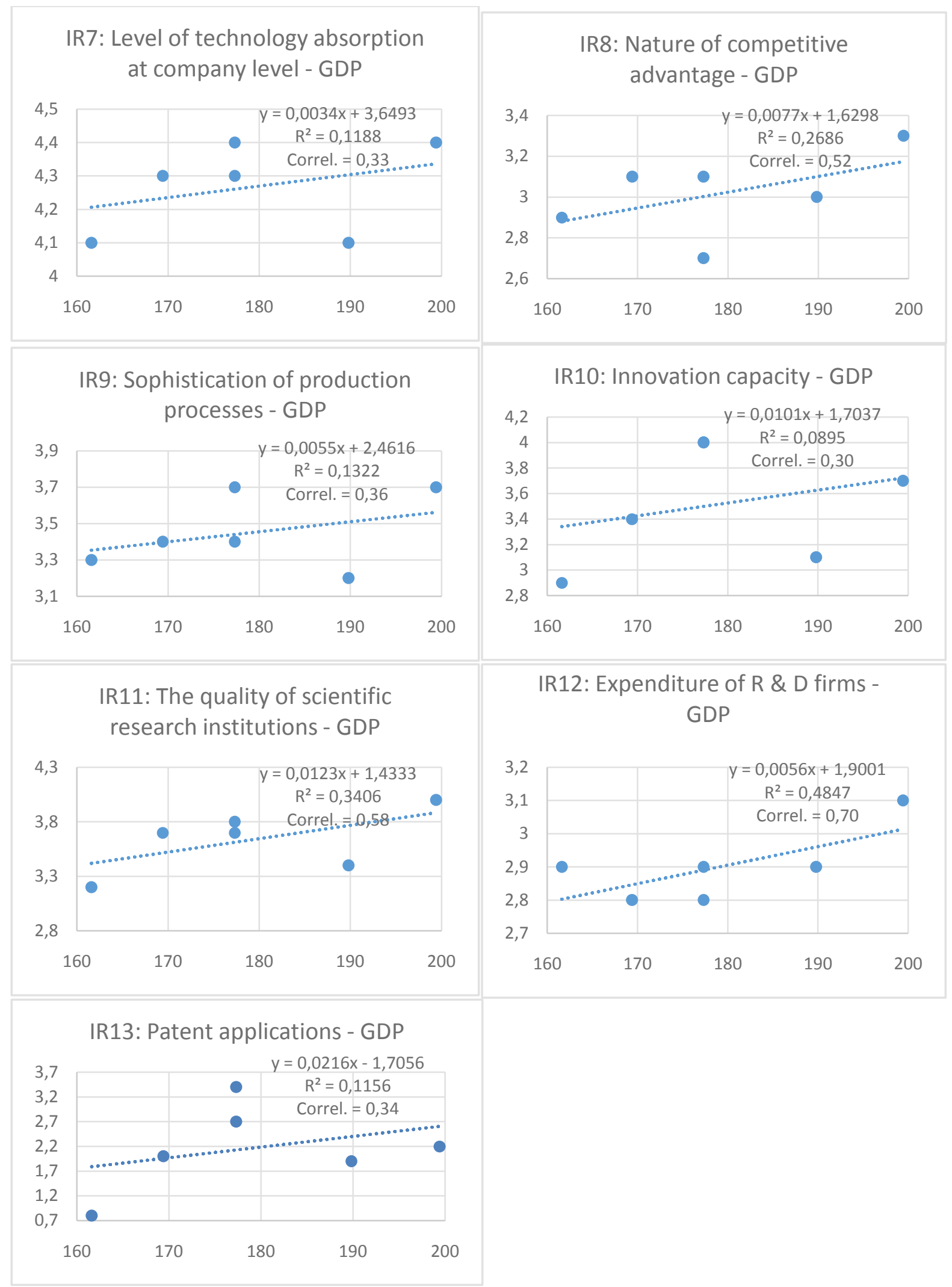

Figure 1.b: Correlation analysis between intangible resource variables (IR7-13) and GDP

Source: own processing using the EXCEL software 


\section{Conclusions}

Intellectual capital and the competitiveness of nations are strongly linked, both being the result of knowledge within countries. Also, national wealth, competitiveness and national intellectual capital are some of the most important goals of a nation. Various studies have shown that these goals are strongly and directly interconnected, thus being able to create great synergies for countries.

Intangibles positively affect labour productivity [15] and ensure future earnings for countries as well as for organizations [1], [16]. At present, intangibles have become the most important resource for wealth creation and national progress [17], [18]. During this post-financial crisis, it became clear that countries with higher national intangible resources more easily outperformed the crisis and recovered more strongly than those with intangible resources at a lower level [19].

Despite the importance of intangible resources at national level and the fact that they are an important factor in determining economic growth in the current knowledgebased economy, we appreciate that Romania's position in the international context regarding intangible assets is very poor, with many weak points regarding research and innovation performance compared to other EU Member States. Therefore, there is a need in our country to re-evaluate the areas where all efforts need to be focused to stimulate innovation performance, to properly manage national intangible resources, a crucial process for improving quality of life.

\section{References}

[1] Malhotra, Y., Measuring knowledge assets of a nation: knowledge systems for development, Invited Research Paper Sponsored by the United Nations Department of Economic and Social Affairs. Keynote Presentation at the Ad Hoc Group of Experts Meeting at the United Nations Headquarters, New York City, 2003.

[2] Malhotra Y., Knowledge Management and New Organization Forms: A Framework for Business Model Innovation, Information Resources Management Journal, Jan-Mar, 13(1), 5-14, 2000.

[3] Solow, R., A contribution to the theory of economic growth, Quaterly Journal of Economics, nr 70, 1956.

[4] McQuinn K. and Whelan K., Solow (1956) as a model of cross-country growth dynamics, Oxford Review of Economic Policy 23 (1), 45-62, 2007.

[5] Pulic, A., Value creation efficiency at national and regional levels: case study-Croatia and the European Union, in Bonfour, M., Edvinsson, L. (Eds) Intellectual Capital for Communities, Nations, Regions, and Cities, Elsevier Butterworth-Heinemann, Burlington, MA, 2005.

[6] Dunning, J.H., Regions, Globalization, and the Knowledge-Based Economy, Oxford University Press, Oxford, 2000.

[7] Foray, D., The Economics of Knowledge, MIT Press, Cambridge, MA, 2004.

[8] Labra R. and Sánchez M. P., National intellectual capital assessment models: a literature review, Journal of Intellectual Capital, Vol. 14, 4 pp. 582 - 607, 2013.

[9] Ståhle P., Ståhle S. and Lin C. Y.Y., Intangibles and national economic wealth - a new perspective on how they are linked, Journal of Intellectual Capital, Vol. 16 Iss 1 pp. 20 $-57,2015$.

[10] Stan S., Intangible resources - new creative engines for welfare in organizations, Revista Strategii Manageriale ISSN 1844 - 668X, Anul X, nr. V (34) / 2017, pp. $763-$ $771,2017$. 
[11] Ståhle, S. and Ståhle, P., Towards measures of national intellectual capital: a critical analysis of the CHS model, Journal of Intellectual Capital, Vol. 13 No. 2, pp. 164-177, 2012.

[12] Weziak, D., Measurement of national intellectual capital: application to EU countries, IRISS Working Paper Series No.13, INSEAD, November Lifferdange, 2007.

[13] Corrado, C., Hulten, C. and Sichel, D., Intangible capital and US economic growth, Review of Income and Wealth, Vol. 55 No. 3, pp. 661-685, 2009.

[14] Lopez Ruiz V.R., Nevado Pena D., Alfaro Navarro J.L., Badea L., Grigorescu A. and Voinea L., Measurement of National Non-Visible Wealth through Intellectual Capital, Romanian Journal of Economic Forecasting, 3/2011, pp. 200-212, 2011.

[15] Nakamura, L.I., Intangible assets and national income accounting, Review of Income and Wealth, Vol. 56 No. 1, pp. S135-S155, 2010.

[16] Bontis, N., National intellectual capital index: a United Nations initiative for the Arab region, Journal of Intellectual Capital, Vol. 5 No. 1, pp. 13-39, 2004.

[17] Bounfour, A. and Edvinsson, L., IC for Communities, Nations, Regions, Cities and other Communities, Elsevier, Butterworth-Heinemann, Burlington, 2005.

[18] Lin, C.Y.Y. and Edvinsson, L., National intellectual capital: comparison of the Nordic countries, Journal of Intellectual Capital, Vol. 9 No. 4, pp. 525-545, 2008.

[19] Lin, C.Y.Y., Edvinsson, L., Chen, J. and Beding, T., National Intellectual Capital and the Financial Crisis in Greece, Italy, Portugal, and Spain (ISBN: 978-1-4614-5989-7), Springer Science and Business Media, LLC, New York, NY, pg. 71, 2013. 